\title{
Stimulating teachers' participation in lifelong training programs
}

\author{
Daniel Mara ${ }^{1}$, and Daniel Hunyadi ${ }^{2, *}$ \\ ${ }^{1}$ University "Lucian Blaga" of Sibiu, Department of Teacher Training, Calea Dumbrăvii 34, Sibiu, \\ Romania \\ ${ }^{2}$ University "Lucian Blaga" of Sibiu, Department of Mathematics and Informatics, Dr. Ratiu No.5-7, \\ Sibiu, Romania
}

\begin{abstract}
In this paper we will present the main ways to stimulate teacher participation in lifelong education programs, we have conducted during a POCU project, implemented between April 11, 2018 and December 10,2020 . The purpose of this research approach was to demonstrate the role of providing incentives to teachers who participate in continuing education programs. The study started from the general hypothesis that providing the opportunity to obtain some types of incentives contributes to motivating teachers' participation in continuing education programs, as well as to obtaining very good results in the evaluation process. The research methods used to carry out the research approach were: the survey method and the tool used was a questionnaire on the quality of continuing education programs in which teachers participated; the method of analyzing the products of the teachers' activity and the tool used was the portfolio for each methodology of the stimulant offered type. The main types of incentives provided to teachers in the project were: providing support tools, performance incentives and reward incentives for the teachers. By disseminating and multiplying the good practices regarding the continuous training process, the quality of the educational act with long-term effects will be ensured.
\end{abstract}

\section{Introduction}

The continuous training of the teaching staff in pre-university education is achieved through a system of institutions, organizations, and their structures, through projects developed and implemented for this purpose. Lifelong educational programs contribute to the training and development of teachers' psycho-pedagogical and specialized skills, essential skills for the continuous adaptation to change process, in all levels of the education system.

In Romania, Ministry of National Education's Order no. 4476/2016 [7] were approved the professional standards of lifelong training for teaching positions in pre-university education on educational levels and stages of professional development, on teaching degrees and lifelong education every 5 years. Three broad categories of skills are mentioned, namely: specialized skills, professional skills, and transversal skills. According to this document, specialized skills are defined to describe each qualification provided by university's study

\footnotetext{
* Corresponding author: daniel.hunyadi@ulbsibiu.ro
} 
programs, and professional skills have to be placed at the service of the children development, students and other beneficiaries of the educational process. From this perspective, the professional standards of teachers refer mainly to the teaching activity, thus becoming structured on the following priority areas:

- Designing the educational activity;

- $\quad$ Leading and monitoring the educational process;

- Integration and use of ICT in education;

- Evaluation of educational activities;

- Knowledge, counseling and differentiated treatment of students;

- Management of the class / group of students / children;

- Institutional development of the school and the school-community partnership;

- Career and personal development management;

- Applied educational research.

All these standards are correlated with the needs of students and with the process of adaptation and flexibility of all curricular components to the dynamics of change in society. The professionalization of teachers involves the formation of new skills as well as the development of existing skills, already formed in accordance with the specific role requirements. Therefore, by means of continuous educational programs the following competences are developed [6]:

- scientific skills (knowledge, skills, basic concepts attitudes, specialization field principles, concepts on the scientific methodology of knowledge, research, on the formulation of interpretations and their support with relevant arguments, etc.).

- psycho-pedagogical competences (knowledge, skills, attitudes, construction of different components of students' personality: ability to determine the degree of difficulty for each learning material, ability to make learning material accessible by finding the most appropriate methods and means, ability to understand the student, to perceive his inner world, creativity in psycho-pedagogical work, the ability to create new models of instructive-educational influence, depending on the requirements of each educational situation, etc.).

- psychosocial skills (knowledge, skills, attitudes towards optimizing interpersonal relationships and taking on responsibilities: the ability to take on a different role, the ability to easily and appropriately establish relationships with others, the ability to influence the group of students, but also isolated individuals, the ability to communicate easily and effectively with students, the ability to properly use power and authority, the ability to adopt different leadership styles, etc.).

- management skills (knowledge, skills, attitudes regarding the management of situations specific to the educational field: the ability to organize students in relation to training tasks and to establish responsibilities in the group, the ability to establish cooperative relationships, an appropriate climate in the group of students and to resolve conflicts, the ability to take responsibility, the ability to guide and coordinate, guide and motivate, to make decisions depending on the situation).

In the current context, the professionalization of teachers is achieved in a paradigm in which the emphasis is on student-centered training, adaptation to the educational context and differences between students, finding effective solutions to overcome obstacles, creating classroom learning contexts, etc.

The lifelong training of teachers contributes to the existence of quality educational services achieved through specific methods and techniques that aim to educate and train various categories of beneficiaries [2]. 


\section{Lifelong educational programs adapted to disadvantaged educational contexts}

The project entitled "Development and implementation of innovative motivational and didactic tools for the inclusive schools of Sibiu", having as funding source POCU/73/6/6/105299, co-financed by the European Social Fund through POCU 2014-2020, Priority Axis 6, Investment Priority 10i, Specific Objective 6.6, call for projects POCU / $73 / 6 / 6$ / Improving the skills of pre-university teaching staff in order to promote quality educational services oriented to the needs of students and inclusive schools, was implemented by "Lucian Blaga" University of Sibiu (ULBS), as a Beneficiary, in partnership with the Sibiu County School Inspectorate (ISJ). Within the project, two continuing education programs were developed: Inclusive school in today's society and Interactive learning and the development of critical thinking.

The general and specific objectives of the project were to improve skills for 347 teachers and support them by developing and implementing innovative motivational and teaching tools, to ensure quality educational services and school inclusion for students in 10 preuniversity education disadvantaged units in the counties: Sibiu (School Center for Inclusive Education Dumbrăveni, School Center for Inclusive Education Mediaş, School Center for Inclusive Education Turnu Roșu, School Center for Inclusive Education No. 1 Sibiu, Iacobeni Technological High School, Biertan Secondary School, Brădeni Secondary School; Brașov (Cața Secondary School); Alba (School Center for Inclusive Education Alba Iulia, Technological High School "Timotei Cipariu" Blaj).

The intervention proposed in this project was also addressed to the managerial staff of the 10 educational units by providing skills and knowledge to support the managerial process in order to prevent school dropout, developing the school-community-parent partnership and attracting resources to increase the sustainability of the inclusive educational process.

In the first stage, the two continuing education programs were provided: "Inclusive school in today's society" and "Interactive learning and the development of critical thinking". Both have been designed to meet the needs of teachers working in disadvantaged schools, where they teach and educate students with high educational risk study, in order to increase their motivation for continuing education, necessary to improve the educational process. An important objective of these courses was to reduce learning barriers, respect the particularities of each student, design and achieve a differentiated and individualized teaching approach [4].

Subsequently, a teacher mentoring program was developed, in which each mentor monitored approximately 12 teachers from each training series, and at the end he prepared a report for each monitored teacher. Following the mentoring activities organized in each school, the aim was to create a network of teachers and support staff to be involved in decision-making and solving problems that arise in the school and in the community, a network that will support and contribute to the dissemination of good practices. to identify methods to support the long-term sustainability of the inclusive educational process within the educational units participating in the project.

In order to exchange best practices and create a network of teachers and support staff in order to disseminate knowledge, methods and practices of quality assurance in education at pre-university level, workshops were organized at the level of each associated school for improving communication, exchange of ideas and relationships involving the school-familycommunity triangle [5].

As part of these actions, possible situations of segregation identified in schools were analyzed and measured, in order to identify means by which they can be reduced and eliminated. These actions were also supported due to the involvement of NGO representatives and economic actors, the aim being to facilitate the identification and creation of partnerships and networks between school - family - community, in order to develop and 
implement future projects that respond to the needs and challenges of that community. At the same time, the teachers from the target group who obtain incentives for performance because of the results obtained by participating in training courses, will be involved in an exchange of good practices by organizing a workshop or conducting a demonstration lesson in a partner school.

\section{Research design}

Between 2018-2020, we initiated and carried out a research on the following theme: the stimulation of teachers' participation in continuous training programs.

The purpose of this research approach was to demonstrate the role of providing incentives to teachers who participate in continuing education programs. The study started from the general hypothesis that providing the opportunity to obtain some types of incentives contributes to motivating teachers' participation in continuing education programs, as well as to obtaining very good results in the evaluation process.

The research methods used to carry out the research approach were:

- the survey method and the tool used was a questionnaire on the quality of continuing education programs in which teachers participated.

- the method of analyzing the products of the teachers' activity and the tool used was the portfolio for each methodology of the stimulant offered type.

As a method of psycho-pedagogical research, the survey involves the systematic collection of information about the activity of teachers participating in training and their interpretation in order to detach the meanings [1]. In the investigative approach we opted for the questionnaire-based investigation, which facilitated the obtaining of relevant information in the report with the proposed objectives.

The method of analyzing the portfolios / products of the teachers' activity was used in order to identify the level of involvement of teachers in the evaluation process to obtain incentives and to evaluate the component tools in the portfolio. Through the portfolio was registered the level of involvement of teachers in the process of improving the educational act [1].

The main types of incentives provided to teachers in the project were: the provision of support tools, performance incentives and incentives to reward teachers. We will present the results obtained from the investigation, on the three categories of incentives granted to teachers participating in continuing education programs.

\subsection{Providing support tools}

The support tools were applied to sustain the process of carrying out the practical activities / internships in the target school, in order to ensure the material resources necessary for the implementation and improvement of the skills obtained in the theoretical component. The support tool (in the form of a grant) was given to teachers for teaching materials, resources for curricular adaptation and for carrying out educational projects inside and outside the school. In the first three months of training, each teacher who expressed a desire to run into the selection process in order to provide the support tool for the activities / internships, developed and taught the Portfolio of the internship project, which included: argument description of the need to organize and carry out the practical activity in which the instrument is used; practical activity plan; elaboration of the estimated budget; added value. These portfolios were assessed by an evaluation team, which includes, among others, the methodological expert and training managers from ULBS and ISJ. Following the mentoring activities and the application of support tools, a monitoring and evaluation of the effectiveness of the intervention was carried out. This monitoring was carried out in several 
stages and followed, through comparative studies, indicators related to the increase of the school attendance rate of children at educational risk, the improvement of educational performances and the development of educational activities through partnership.

The support tools were provided to a number of 97 teachers, out of the 347 teachers who were certified in the training programs. This means that $27.95 \%$ of the participating teachers obtained a support tool. Table 1 and Figure 1 show, for each school, the percentage of teachers, out of the total number of participating teachers, who received support tools.

Tabel 1. Support tools provided in each school

\begin{tabular}{|c|l|c|}
\hline No. & \multicolumn{1}{|c|}{ Name of the school } & $\begin{array}{c}\text { Teachers } \\
\text { percentage }\end{array}$ \\
\hline 1 & Turnu Roșu School of Inclusive Education & $23.26 \%$ \\
\hline 2 & $\begin{array}{l}\text { School Center for Inclusive Education No. } \\
\text { 1 Sibiu }\end{array}$ & $12.05 \%$ \\
\hline 3 & Iacobeni Technological High School & $17.86 \%$ \\
\hline 4 & Cata Secondary School & $52.63 \%$ \\
\hline 5 & $\begin{array}{l}\text { Alba Iulia School Center for Inclusive } \\
\text { Education }\end{array}$ & $24.39 \%$ \\
\hline 6 & Mediaș Inclusive Education School Center & $29.41 \%$ \\
\hline 7 & $\begin{array}{l}\text { Dumbrăveni School Center for Inclusive } \\
\text { Education }\end{array}$ & $45.45 \%$ \\
\hline 8 & Bradeni Secondary School & $71.43 \%$ \\
\hline 9 & Biertan Secondary School & $83.33 \%$ \\
\hline 10 & $\begin{array}{l}\text { "Timotei Cipariu" Technological High } \\
\text { School Blaj }\end{array}$ & $30.43 \%$ \\
\hline & \multicolumn{2}{|c|}{ Total } \\
\hline
\end{tabular}

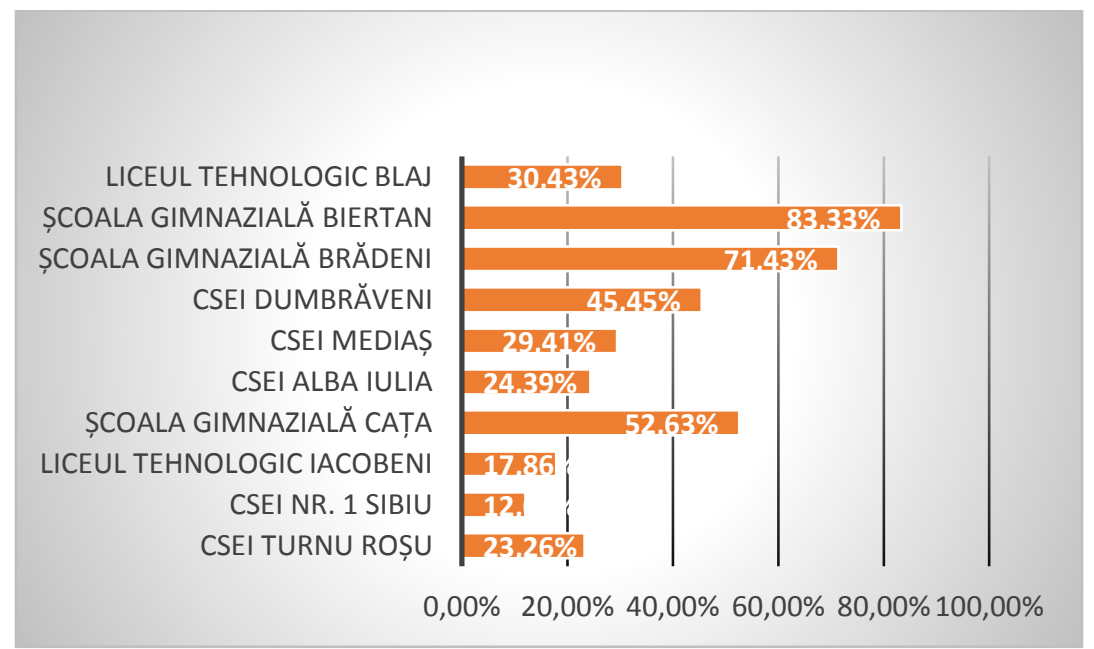

Fig. 1. Accessing support tools

\subsection{Providing performance incentives}

A number of 79 teachers and support staff who worked in the target schools and participated in continuing education / skills development programs benefited from performance incentives (scholarship type). The 100 scholarships available on the project were distributed 
equitably over the 2 years while the training activities took place. These performance incentives were given to teachers who participated in the training and obtained at least the grade "Very Good" in the final evaluations. Only teachers who did not receive performance incentives in the current project were eligible.

Teachers and support staff who wanted to apply for these performance incentives had to develop a personal development plan which included:

- evidence of students 'attendance at their own subjects in the school year prior to the training and how the students' attendance rate will improve;

- evidence of students 'own subjects in the school year prior to training and how to improve students' educational performance.

Performance incentives were awarded to 79 teachers, out of the 347 teachers who were certified in the training programs. This means that $22.77 \%$ of the participating teachers obtained an incentive for performance. Table 2 and Figure 2 show, for each school, the percentage of teachers, out of the total number of participating teachers, who received incentives for performance.

Tabel 2. Performance incentives provided in each school

\begin{tabular}{|c|l|c|}
\hline $\begin{array}{c}\text { Nr. } \\
\text { crt. }\end{array}$ & \multicolumn{1}{|c|}{ Denumire școală } & $\begin{array}{c}\text { Procent cadre } \\
\text { didactice }\end{array}$ \\
\hline 1 & Turnu Roșu School of Inclusive Education & $9.30 \%$ \\
\hline 2 & School Center for Inclusive Education No. 1 Sibiu & $27.71 \%$ \\
\hline 3 & Iacobeni Technological High School & $16.07 \%$ \\
\hline 4 & Cata Secondary School & $21.05 \%$ \\
\hline 5 & Alba Iulia School Center for Inclusive Education & $21.95 \%$ \\
\hline 6 & Mediaș Inclusive Education School Center & $35.29 \%$ \\
\hline 7 & Dumbrăveni School Center for Inclusive Education & $36.36 \%$ \\
\hline 8 & Bradeni Secondary School & $0.00 \%$ \\
\hline 9 & Biertan Secondary School & $25.00 \%$ \\
\hline 10 & "Timotei Cipariu" Technological High School Blaj & $30.43 \%$ \\
\hline \multicolumn{2}{|c|}{ Total } & $22.77 \%$ \\
\hline
\end{tabular}

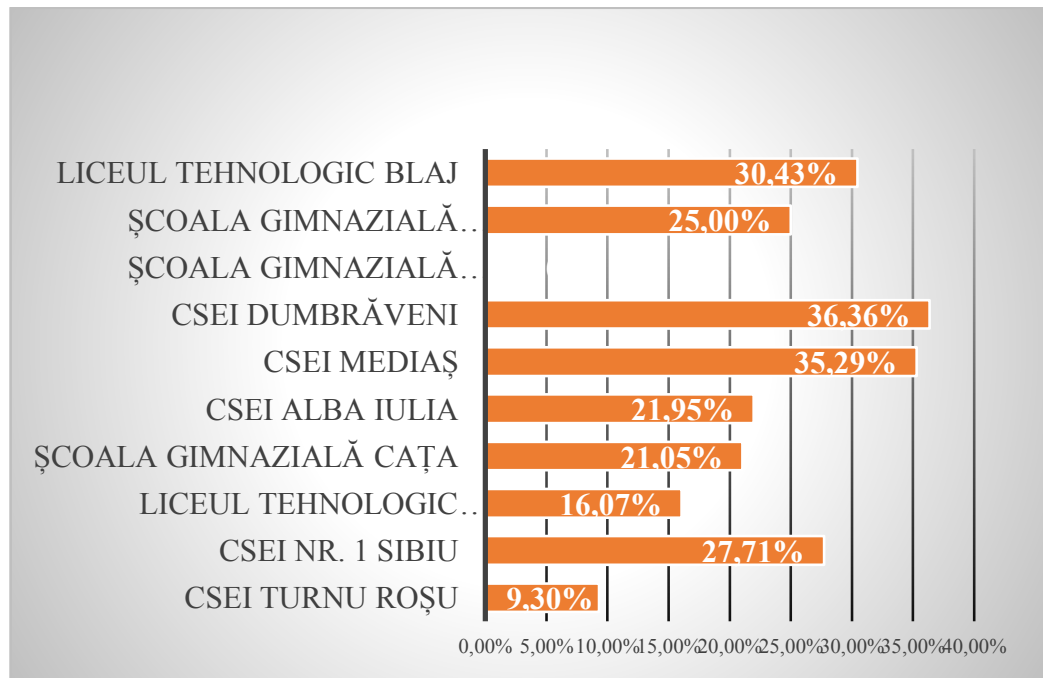

Fig. 2. Accessing performance incentives 


\subsection{Awarding prizes for quality in inclusive education}

Competitions for quality awards in inclusive education for teachers, support staff, school managers and social partner staff in target schools were also organized, which have outstanding results in ensuring a quality inclusive education for children at high educational risk.

Only teachers who obtained at least the grade "Very Good" in the final evaluations of the training courses and did not receive incentives for performance in the current project were eligible. In the first three months of training, each teacher who expressed a desire to run in the selection process for the award for quality in inclusive education, developed and taught to the mentor "Quality portfolio in inclusive education", which included: case study of a student in need of psycho-pedagogical intervention that contained 5 components: personal data, family data, medical data, level of development, school situation;

- personalized intervention plan developed for the selected student that contained: personal data and contents adapted to the learning units;

- curricular adaptation plan for the selected student that contained: specific skills, resources (human, material, informative), contents, teaching strategies and methods for evaluating the results.

A number of 223 teachers, which represented a percentage of $64.26 \%$, were part of the School Centers for Inclusive Education, so they are involved daily in activities with children at high educational risk. The number of children at educational risk is 1099 , which represents a percentage of $36.65 \%$ of the total number of students in the 10 participating schools.

The awards for quality in inclusive education were given to a number of 48 teachers, out of the 347 teachers who were certified in the training programs. This means that $13.83 \%$ of the participating teachers received an award for quality in inclusive education. Table 3 and figure 3 show, for each school, the percentage of teachers, out of the total number of participating teachers, who received this award.

Tabel 3. Award for quality in inclusive education awarded in each school

\begin{tabular}{|c|l|c|}
\hline $\begin{array}{c}\text { Nr. } \\
\text { crt. }\end{array}$ & \multicolumn{1}{|c|}{ Denumire școală } & $\begin{array}{c}\text { Procent cadre } \\
\text { didactice }\end{array}$ \\
\hline 1 & Turnu Roșu School of Inclusive Education & $2.33 \%$ \\
\hline 2 & $\begin{array}{l}\text { School Center for Inclusive Education No. } \\
\text { Sibiu }\end{array}$ & $12.05 \%$ \\
\hline 3 & Iacobeni Technological High School & $5.36 \%$ \\
\hline 4 & Cata Secondary School & $26.32 \%$ \\
\hline 5 & $\begin{array}{l}\text { Alba Iulia School Center for Inclusive } \\
\text { Education }\end{array}$ & $24.39 \%$ \\
\hline 6 & Mediaș Inclusive Education School Center & $17.65 \%$ \\
\hline 7 & $\begin{array}{l}\text { Dumbrăveni School Center for Inclusive } \\
\text { Education }\end{array}$ & $9.09 \%$ \\
\hline 8 & Bradeni Secondary School & $14.29 \%$ \\
\hline 9 & Biertan Secondary School & $41.67 \%$ \\
\hline 10 & $\begin{array}{l}\text { "Timotei Cipariu" Technological High School } \\
\text { Blaj }\end{array}$ & $17.39 \%$ \\
\hline \multicolumn{2}{|c|}{ Total } & $13.83 \%$ \\
\hline
\end{tabular}




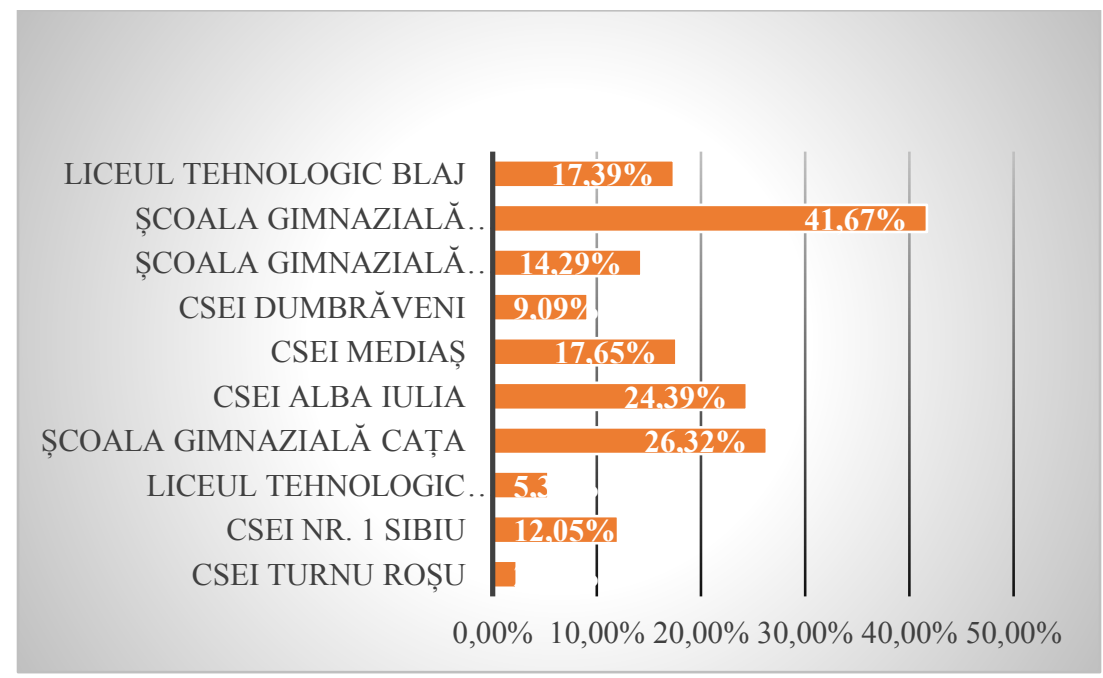

Fig. 3. Accessing awards for quality in inclusive education

\section{Conclusions}

The lifelong professional training of teachers is carried out in relation to the professional standards of teachers. Professional standards are developed according to some priorities, which in turn are multifaceted by the action of factors such as: strengthening the European dimension in the field of education and continuing vocational training of teachers; orientation of the professional development system in accordance with the demands on the labor market; teachers' awareness of the need for lifelong learning; increasing the degree of responsibility regarding the personal development of each teacher; promoting a transparent system of values; recognition of diplomas and professional qualifications [6].

Through this approach of dissemination and multiplication of good practices of activities and teaching methods, the continuity of the educational process with long-term effects will be ensured, aiming at the inclusion of students with educational risk coming from families with limited material and financial resources, children with disabilities etc., thus ensuring them a good start in school and facilitating the educational path to promotion, graduation and then obtaining a job that will ensure their exit from the situation of vulnerability. The network created will promote the dissemination of inclusive teaching methods and learning tools (educational resources and multimedia) in disadvantaged schools at the county level, cooperation and teamwork being the elements that ensure the premises of a good educational process.

Another important element around which the activity of the network members will be oriented, with long-term positive impact and effects, is the reduction of cases of segregation identified in schools and the adoption of customized solutions to reduce and eliminate them, putting in the first place. plan the interest of children, by involving the community and parents in the activity and social and school life, thus improving the interaction of the constituent factors of school education. Teachers need to become agents of change, to lead students from what they are to what we want them to be [3].

\section{References}

1. M. Bocoș, Theory and practice of pedagogical research (Casa Cărții de Știință Publishing House Cluj Napoca, 2003). 
2. C. Cucoș (coord.), Psychopedagogy for final exams and teaching degrees. 3rd edition revised and added, (Polirom Publishing House Iași, 2009)

3. J. Hattie, Visible learning: a guide for teachers (Trei Publishing House București, 2014)

4. D. Mara, D. Hunyadi (coord.) Interactive learning and the development of critical thinking (University Publishing House București, 2018)

5. D. Mara, D. Hunyadi. Inclusive school in today's society (University Publishing House Bucureşti), (2018)

6. D. Potolea, I. Neacșu, R.B. Iucu, I.O. Pânișoară (coord.), Psycho-pedagogical training. Handbook for completion and teaching degree II (Polirom Publishing House Iași, 2008)

7. http://www.cdep.ro/pls/legis/legis_pck.htp_act?ida=141606, [Accessed 15.12.2020] 